\title{
Cutaneous Granulomas in Ataxia Telangiectasia and Other Primary Immunodeficiencies: Reflection of Inappropriate Immune Regulation?
}

\author{
L.Y.T. Chiam ${ }^{\text {a }}$ M.M.M. Verhagen ${ }^{b}$ A. Haraldsson ${ }^{f} \quad$ N. Wulffraat ${ }^{d} \quad$ G.-J. Driessen ${ }^{e}$ \\ M.G. Netea ${ }^{c}$ C.M.R. Weemaes ${ }^{b}$ M.M.B.Seyger ${ }^{a}$ M. van Deuren ${ }^{c}$
}

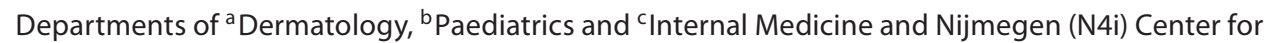
Immunodeficiency \& Autoinflammation, Radboud University Nijmegen Medical Centre, Nijmegen, ${ }^{d}$ Department of Paediatric Immunology, Wilhelmina Children's Hospital/University Medical Centre Utrecht, Utrecht, and eSophia Children's Hospital, Erasmus University, Rotterdam, The Netherlands; ${ }^{f}$ Children's Hospital Iceland, Landspitali University Hospital Reykjavík and University of Iceland, Faculty of Medicine, Reykjavík, Iceland
\end{abstract}

\section{Key Words}

Ataxia telangiectasia $\cdot$ Cutaneous granulomas - Immunodeficiency $\cdot$ B cells T cells $\cdot$ Natural killer cells

\begin{abstract}
Background: Non-infective cutaneous granulomas with unknown pathogenesis occur in various primary immunodeficiencies (PIDs) including ataxia telangiectasia (A-T). Objective: To find a common immunological denominator in these cutaneous granulomas. Methods: The dermatological and immunological features of 4 patients with A-T and cutaneous granulomas were described. The literature on skin granulomas in A-T and in other PIDs is reviewed. Results: All 4 A-T patients had progressive granulomas on their limbs and showed decreased $\lg G$ and $\lg A$ concentrations with normal IgM levels. They had a marked decrease in B cells and naïve $T$ cells coinciding with the appearance of the cutaneous granulomas. Similar B- and T-cell abnormalities were described in patients with other PIDs with skin granulomas. Conclusions: We hypothesize that the pathogenesis of these skin granulomas is related to immune dysregulation of macrophages due to the absence of naïve T cells
\end{abstract}

with an appropriate T-cell receptor repertoire and the unopposed activity of $\gamma \delta \mathrm{T}$ cells and/or natural killer cells.

Copyright $\odot 2011$ S. Karger AG, Basel

\section{Introduction}

Systemic granulomas develop in response to infections like Mycobacterium tuberculosis and Schistosoma mansoni, to foreign material or in the context of noninfectious diseases like sarcoidosis and granulomatosis with polyangiitis (Wegener's granulomatosis). Cutaneous granulomas with unknown aetiology not related to infectious or systemic diseases occur uncommonly in various primary immunodeficiencies (PIDs).

Ataxia telangiectasia (A-T) is caused by a mutation in the A-T Mutated gene, localized on chromosome 11 (11q22-23), and its protein is involved in cell cycle control and DNA repair [1]. A-T is characterized by progressive cerebellar ataxia, oculocutaneous telangiectasia, immunodeficiency, predisposition toward malignancy, elevated $\alpha_{1}$-fetoprotein levels, rearrangement of chromosome 7 and 14, and increased radiosensitivity. In addition, A-T patients may display a wide range of humoral and cellular immune system abnormalities and variable lymphopenia [2]. Here we describe $4 \mathrm{~A}-\mathrm{T}$ patients who developed cutaneous granulomas and review the literature of all $(\mathrm{n}=17)$ reported A-T patients with skin granulomas. In addition, we review the literature on cutaneous granulomas in all known other PIDs. Based on the obtained data we propose that unexplained cutaneous granulomas in PID patients can be considered as a manifestation of dysregulation in wound healing and tissue repair explained by the immune defects inherent in these PIDs.

\section{Patients and Methods}

In mid-2010 there were 52 patients known in the Dutch A-T registry. In all, the diagnosis was confirmed by chromosomal analysis. Cutaneous granulomas developed in $4(8 \%)$ of these 52 patients. Unfortunately, 1 patient was lost to followup. In this article, we discuss the 3 Dutch A-T patients and include 1 Icelandic A-T patient with cutaneous granulomas who shared the same immunological profile. All 4 patients had truncating mutations in

\section{KARGER}

Fax +41 613061234 E-Mail karger@karger.ch www.karger.com www.karger.com/drm
M. van Deuren

Department of Internal Medicine and Nijmegen Centre for Immunodeficiency and Auto-Inflammation, Radboud University Nijmegen Medical Centre PO Box, NL-6500 HB Nijmegen (The Netherlands)

E-Mail m.vandeuren@aig.umcn.nl 
Table 1. Immunological characteristics of the 4 described A-T patients with skin granulomas at the time of diagnosis of A-T and of granulomas

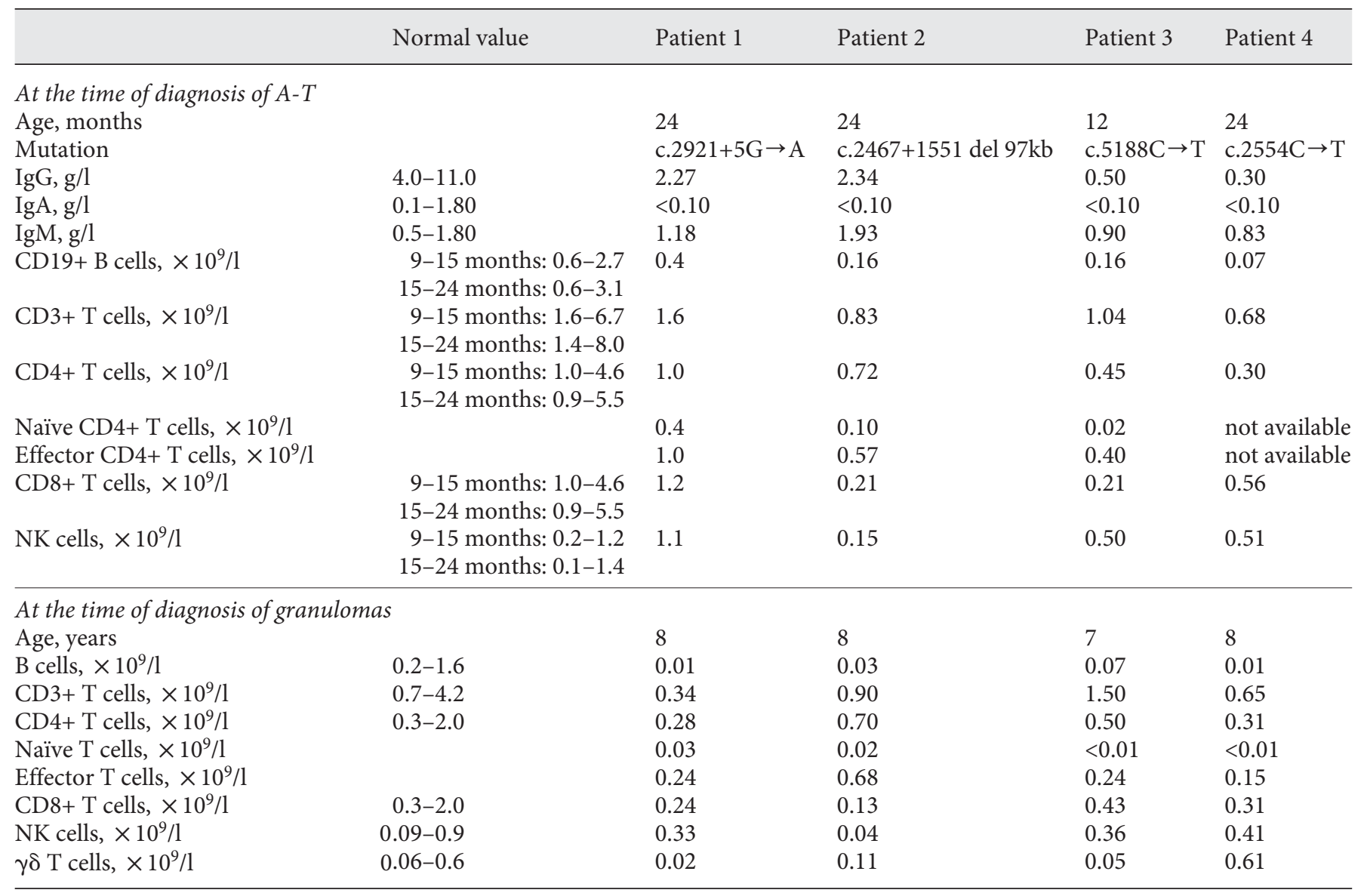

the ATM gene (table 1) without ATM kinase activity. We also reviewed the existing literature on cutaneous granulomata in patients with A-T and in patients with other PIDs. To this end a search was done in PubMed with the MeSH words 'granuloma', 'skin', 'cutaneous' and all known PIDs as reported by the International Union of Immunological Societies Expert Committee on Primary Immunodeficiencies [3]. Included were all primary publications published in English, German and French. Ten primary reports were found describing cutaneous granulomas in A-T [4-13] and a series of articles reporting skin granulomas in other PIDs [14-26]. For common variable immunodeficiency (CVID), often associated with granulomas in various organs, only the recently published article of Ardeniz and Cunningham-Rundles [23] dealing with skin granulomas was included.

\section{Case Reports}

\section{Patient 1}

An 8-year-old girl of Moroccan ancestry presented with a 1-year history of tender lesions on the left leg appearing after a fall. It started as an ulcer, which progressively enlarged to involve her entire lower leg. She had had a diagnosis of A-T at 2 years of age on the basis of cerebellar ataxia, elevated $\alpha$-fetoprotein, recurrent sinopulmonary infections with low IgG, deficient $\operatorname{IgA}(<0.10 \mathrm{~g} / \mathrm{l})$ but normal IgM ( $1.18 \mathrm{~g} / \mathrm{l}$; table 1$)$. At the time of appearance of the granulomas, she had almost absent CD19+ B cells, extremely low naïve $(\mathrm{CD} 3+\mathrm{CD} 4+\mathrm{C} 45 \mathrm{RA}+) \mathrm{T}$ cells and normal natural killer $(\mathrm{NK})$ cells in her peripheral blood (table 1). Clinical examination revealed multiple tender ulcers on the left anterior shin and below her knee. The ulcers had irregular ragged edges with clean fibrinous bases. The surrounding skin was erythematous, atrophic and had surface telangiectasia (fig. 1). A biopsy from the lesions showed palisading granulomas consisting of histiocytes and polynuclear giant cells with necrosis. Alcian blue stain, Ziehl-Neelsen and periodic acid-Schiff stain were negative as were cultures for micro-organisms. The lesions continued to deteriorate despite topical tacrolimus, topical corticosteroids, oral antibiotics, tuberculostatics and increment of the dosage of intravenous immunoglobulin. Slight improvement was noted when she was on oral corticosteroids given for her interstitial lung disease. She suffered from recurrent chest infection and succumbed due to respiratory failure at 14 years of age.

\section{Patient 2}

Patient 2, the son of consanguineous Dutch parents, was diagnosed as having 


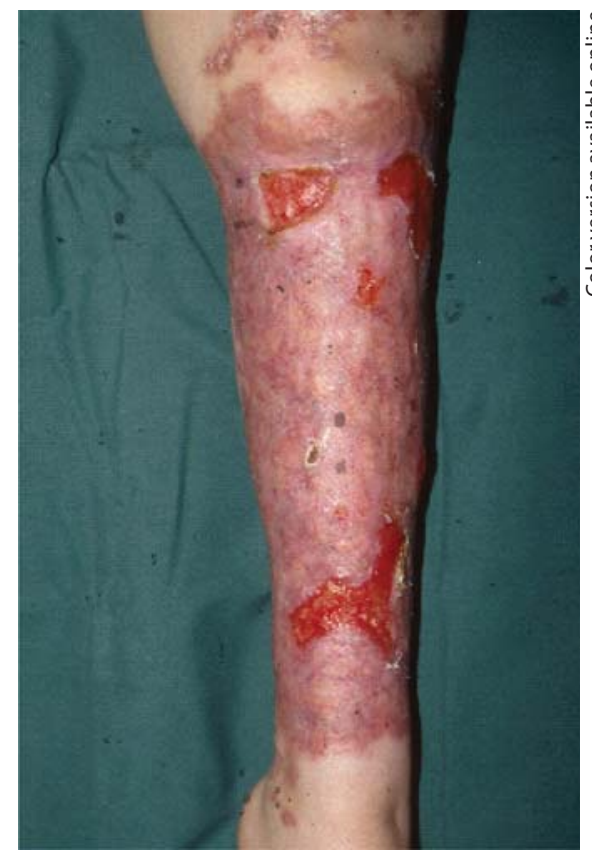

Fig. 1. Ulcer on the leg with surrounding erythema, atrophy and telangiectasia of patient 1.

A-T at the age of 2 years based on cerebellar ataxia, ocular telangiectasia, recurrent upper respiratory tract infections and low IgG, absent IgA and slightly increased IgM $(1.93 \mathrm{~g} / \mathrm{l}$; table 1$)$. At the age of 6 years he developed progressive lesions on the arms and legs. Clinical examination at 8 years old showed erythematous atrophic plaques on his right hand and left leg associated with surface telangiectasia (fig. 2) and shallow tender ulcers on his right wrist and left foot. At that time, he had markedly decreased CD19+ B cells, low CD3+CD4+CD45RA+ naïve $\mathrm{T}$ cells and low but detectable NK cells in his peripheral blood (table 1). On histology, granulomatous inflammation was seen in the deeper half of the dermis consisting of epithelioid histiocytes and polynuclear giant cells surrounding a necrotic centre. Small amounts of mucin were demonstrated in the centre of the granuloma. Culture for micro-organisms, Ziehl-Neelsen stain and periodic acid-Schiff stain were negative. The histological and immunohistochemical features of his granulomas were published previously [27]. Notably, the intralesional CD4+/CD8+ ratio was low (0.28). The lesions did not respond to topical or intralesional corticosteroids or topical and

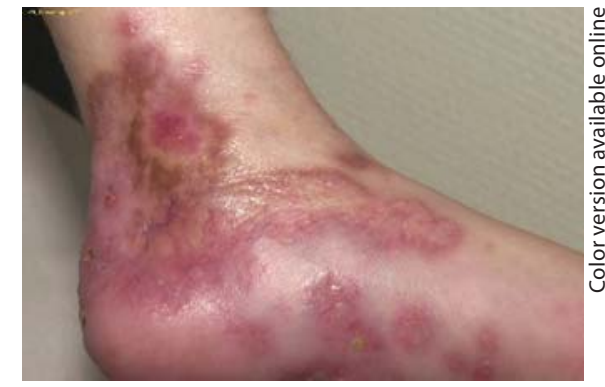

Fig. 2. Erythematous atrophic plaques associated with telangiectasia on the leg of patient 2 .

systemic antibiotics. Although some improvement was noted with topical tacrolimus, the plaques on his limbs persisted. At the age of 12 , he developed a premalignant B cell lymphoma which regressed with rituximab. Unfortunately, a year later, he was discovered to have nasopharyngeal carcinoma and passed away.

\section{Patient 3}

Patient 3, a girl of Afghan ancestry, was diagnosed as having A-T when she was 1 year old on the basis of a positive family history ( 2 siblings had A-T) and investigations revealing elevated $\alpha$-fetoprotein, low IgG, deficient IgA and normal IgM (table 1). At 7 years old, she presented with 2 discrete well-demarcated plaques on her left lower leg, which appeared after an insect bite. Clinical examination showed a 5 by $2 \mathrm{~cm}$ dusky-red, scaly, well-demarcated plaque with central crusting on her left lower leg and another similar plaque on her right forearm. The lesions were not tender. At that time, she had almost absent $\mathrm{CD} 19+\mathrm{B}$ cells, very low $\mathrm{CD} 3+\mathrm{CD} 4+$ CD45RA+ naïve $\mathrm{T}$ cells and normal NK cells in her peripheral blood (table 1).

\section{Patient 4}

From the age of 6 months, this Icelandic girl suffered from recurrent otitis media and pneumonia. When she was 16 months old, immunological investigations revealed IgG and IgA deficiency with normal IgM (table 1). She was started on immunoglobulin substitution and prophylaxis for Pneumocystis jirovecii pneumonia. She developed cerebellar ataxia at 18 months. At 8 years old, she developed, without distinct triggers, erythematous indurated plaques on her face, thighs and legs. The lesions on her face measured be- tween 0.5 and $4 \mathrm{~cm}$. They were non-tender, not ulcerated, erythematous, slightly indurated but not fixed to the underlying structures. A biopsy showed granulomatous inflammation. Alcian blue, ZiehlNeelsen and periodic acid-Schiff stains were normal, and repeated cultures and polymerase chain reaction for micro-organisms were negative. At the time of diagnosis of the granulomas, she was found to have a significantly decreased number of CD19+ B cells, low CD4+ T cells but normal NK cells in her peripheral blood (table 1). Treatment including topical and intralesional steroids, topical tacrolimus, oral antibiotics, oral antifungal agents and etanercept were unsuccessful. With oral steroids, the granulomas decreased significantly but relapsed after withdrawal. Control of the granulomas was again obtained with reintroduction of steroids that were maintained at low doses.

\section{Review of the Literature}

We traced in the literature 17 reported A-T patients with cutaneous granulomas [4-13] (table 2). There was a female preponderance (13 females, 4 males) compared with equal sex distribution in A-T patients in general. The age at presentation of the cutaneous granulomas ranged from 1.5 to 31 years. The duration of skin lesions before diagnosis varied from 11 months to 5 years. Interestingly, in 4 of the reported patients, the onset of granulomas antedated the diagnosis and the classical cutaneous features of A-T. All patients presented in the literature, including ours, had lesions on the limbs. The second most common site was the face, while only a quarter of the patients had lesions on their trunk.

In the reported patients, the granulomas were described to be well-defined erythematous indurated papules and plaques, which slowly enlarged and became scaly. They were usually small, less than $5 \mathrm{~cm}$ in diameter, though lesions up to $10 \mathrm{~cm}$ were reported. Most had central atrophy with occasional ulceration and surface telangiectasia. The lesions healed with hyperpigmentation. Tenderness was noted in 3 of the 17 reported patients whereas 2 of our 4 patients had significant pain.

Immunoglobulin levels were measured in only 8 of the 17 reported patients. Five had IgG deficiency; 3 had normal total $\mathrm{IgG}$, although in one $\operatorname{IgG}_{2}$ was low (IgG subclasses were not measured in the other 
Table 2. Immunological characteristics of $\mathrm{A}-\mathrm{T}$ patients in general and in patients reported in the literature with skin granulomas

\begin{tabular}{|c|c|c|c|c|c|c|c|c|c|c|c|c|}
\hline & $\begin{array}{l}\text { Number } \\
\text { of patients }\end{array}$ & $\begin{array}{l}\text { Age } \\
\text { years }\end{array}$ & IgG & IgA & $\operatorname{IgM}$ & $\mathrm{IgG}_{2}$ & B cells & $\begin{array}{l}\text { CD3+ } \\
\text { cells }\end{array}$ & $\begin{array}{l}\text { CD3+CD4+ } \\
\text { cells }\end{array}$ & $\begin{array}{l}\mathrm{CD} 3+\mathrm{CD} 8+ \\
\text { cells }\end{array}$ & $\begin{array}{l}\gamma \delta \\
\mathrm{T} \text { cells }\end{array}$ & $\begin{array}{l}\mathrm{NK} \\
\text { cells }\end{array}$ \\
\hline A-T (classical) & & & $\mathrm{N}$ & $\downarrow \downarrow \downarrow$ & $\mathrm{N}$ & $\downarrow \downarrow$ & $\mathrm{N}-\downarrow$ & $\mathrm{N}-\downarrow$ & $N-\downarrow$ & $\mathrm{N}-\downarrow$ & $\mathrm{N}$ & $\mathrm{N}$ \\
\hline Fleck et al. [4], 1986 & 1 & 8 & $\downarrow$ & $\downarrow \downarrow \downarrow$ & $\uparrow \uparrow \uparrow$ & & & & & & & \\
\hline Paller et al. [5], 1991 & 8 & & & & & & & & & & & \\
\hline Joshi et al. [6], 1993 & 1 & 7 & $\mathrm{~N}$ & $\downarrow \downarrow \downarrow$ & $\uparrow$ & & & & & & & \\
\hline Murakawa et al. [9], 1998 & 1 & 8 & & & & & & & & & & \\
\hline Sentürk et al. [10], 1998 & 1 & 12 & $\downarrow \downarrow$ & $\downarrow$ & $\mathrm{N}$ & & & & & & & \\
\hline Corbisier et al. [11], 1999 & 1 & 2 & $\downarrow \downarrow$ & $\downarrow$ & $\uparrow \uparrow \uparrow$ & & & & & & & \\
\hline Mitra et al. [12], 2005 & 1 & 4 & $\downarrow$ & $\downarrow \downarrow \downarrow$ & & $\downarrow \downarrow$ & & & & & & \\
\hline Folgori et al. [13], 2010 & 1 & 3 & $\downarrow \downarrow$ & $\downarrow \downarrow \downarrow$ & $\mathrm{N}$ & $\downarrow \downarrow$ & $\downarrow \downarrow$ & $\downarrow$ & $\downarrow$ & $\downarrow$ & & $\mathrm{N}$ \\
\hline
\end{tabular}

2 patients). All 8 patients in whom immunoglobulin levels were reported had markedly decreased IgA levels and normal or elevated IgM. Only in 1 patient were data on B cells, T cells and NK cells available [13]. In this 3-year-old boy, B cell count was decreased $\left(0.04 \times 10^{9} / 1\right)$, $\mathrm{T}$ cells $(\mathrm{CD} 3+)$ were low $\left(0.30 \times 10^{9} / \mathrm{l}\right)$ with a marked predominance of $\mathrm{T}$ cells with a memory phenotype (CD3+CD4+ $\mathrm{CD} 45 \mathrm{RO}+$ ) [13], and NK cell numbers were normal. Interestingly, $\mathrm{T}$ cell rearrangement excision circles in this patient were extremely low for both CD4+ and CD8+ T cells with oligoclonal expansion in most peripheral CD4+ and CD8+ T cells. Also, the T cell receptor (TCR) repertoire in the skin biopsy was skewed [13].

No treatment was shown to be effective. Topical steroids and oral antibiotics did not alter the course of the disease though topical steroids decreased the erythema and scaling of lesions in 2 patients $[4,5]$. Oral steroids in combination with oral antibiotics resulted in slow control in 1 patient in the literature; however, the lesions relapsed after cessation of steroids [12]. Similar control and relapse with the discontinuation of oral steroids was also noted in our fourth patient. Intravenous immunoglobulin therapy had no effect in 3 patients while in another patient, it was reported to induce regression of the lesions $[7,11]$. Local recurrence and enlargement occurred after excision in 1 patient [5]. Paller et al. [5] proposed a trial of topical corticosteroid for granulomas in A-T pa- tients that are not ulcerated, while application of topical mupirocin or non-adherent dressings is most appropriate for ulcerated lesions. For A-T patients with debilitating granulomas, she proposes administration of systemic steroids, to be undertaken with caution in view of their tendency towards progressive sinopulmonary infections.

Our literature search on the occurrence of skin granulomas in other PIDs revealed description of cutaneous granulomas in Nijmegen breakage syndrome (NBS) $[14,15]$, severe combined immunodeficiency caused by deficiency of recombinant activating gene (RAG) [16], Artemis [17] and JAK3 [18], TAP deficiency syndrome [19-21], Griscelli syndrome [22] and CVID [23] (table 3). Three studies on skin granulomas were cancelled: 2 studies describing lesions in a patient with $\mathrm{X}$ linked hyper-IgM [24] and IgA deficiency [25], because from the decription the lesions appeared sarcoid-like not resembling the skin granulomas in A-T, and 1 study on a man with X-linked agammaglobulinaemia [26] because the paper was published in 1991 before the btk gene analysis became available and the description of the patient did not fit to what is now known for X-linked agammaglobulinaemia.

In NBS, a condition caused by a DNA repair defect resembling the defect in $\mathrm{A}-\mathrm{T}$, which is characterized by microcephaly, a special face and combined immunodeficiency, 2 patients with skin granulomas have been described $[14,15]$. Skin granulo- mas have been reported also in severe combined immunodeficiency caused by RAG deficiency [16] (2 patients), Artemis deficiency [17] (1 patient) or JAK3 deficiency [18] (1 patient). In Griscelli syndrome, characterized by partial pigmentary dilution or albinism, frequent infections and neurological abnormalities, defective NK- and T-cell cytotoxicity and uncontrolled lymphocyte and macrophage activation, 1 patient has been described [22]. In patients with HLA class I deficiency (TAP deficiency) [19-21] and in patients with CVID, cutaneous granulomas are reported more frequently. Granulomas in various other organs (lung, liver, lymph nodes, gastro-intestinal tract) are a well-known feature of the subgroup of CVID patients with a defective B cell class switch and low T cells [28].

\section{Discussion}

The principal finding of the current study is the observation of non-infectious dermal granulomas in A-T patients. A-T is a PID associated with defective DNA repair. In $\mathrm{B}$ and $\mathrm{T}$ cells, this defect causes a restricted repertoire of the $B$ cell receptor and the TCR [29]. Approximately $10 \%$ of A-T patients have a deficiency of IgG and IgA and unaffected or even slightly increased IgM levels, which is indicative of a defective CD4+ Th2-cell-dependent switch of B cells in the germinal centre. All our 4 A-T patients with granulomas 
Table 3. Immunological characteristics of patients with other PIDs and skin granulomas

\begin{tabular}{|c|c|c|c|c|c|c|c|c|c|c|c|c|}
\hline PID & $\begin{array}{l}\text { Number } \\
\text { of patients }\end{array}$ & $\begin{array}{l}\text { Age } \\
\text { years }\end{array}$ & IgG & IgA & $\operatorname{IgM}$ & $\mathrm{IgG}_{2}$ & $\mathrm{~B}$ cells & $\begin{array}{l}\text { CD3+ } \\
\text { cells }\end{array}$ & $\begin{array}{l}\mathrm{CD} 3+\mathrm{CD} 4+ \\
\text { cells }\end{array}$ & $\begin{array}{l}\mathrm{CD} 3+\mathrm{CD} 8+ \\
\text { cells }\end{array}$ & $\begin{array}{l}\gamma \delta \mathrm{T} \\
\text { cells }\end{array}$ & $\begin{array}{l}\text { NK } \\
\text { cells }\end{array}$ \\
\hline NBS & & & $N-\downarrow$ & $\downarrow \downarrow$ & $\mathrm{N}$ & $\downarrow \downarrow$ & $N-\downarrow$ & $\mathrm{N}-\downarrow$ & $N-\downarrow$ & $N-\downarrow$ & $\mathrm{N}$ & $\mathrm{N}$ \\
\hline Vogel et al. [15], 2010 & 1 & 9 & $\downarrow \downarrow$ & $\downarrow \downarrow$ & $\downarrow \downarrow$ & & & $\downarrow$ & & & & \\
\hline RAG deficiency & & & $\downarrow \downarrow$ & $\downarrow \downarrow$ & $\downarrow \downarrow$ & $\downarrow \downarrow$ & $\downarrow \downarrow$ & $\downarrow \downarrow$ & $\downarrow \downarrow$ & $\downarrow \downarrow$ & $\mathrm{N}$ & $\mathrm{N}$ \\
\hline Schuetz et al. [16], 2008 & 2 & 3 & $\downarrow \downarrow$ & $\downarrow$ & $\downarrow$ & & $\downarrow \downarrow$ & $\downarrow \downarrow$ & $\downarrow \downarrow$ & $\downarrow$ & $\mathrm{N}$ & $\mathrm{N}$ \\
\hline Artemis deficiency & & & $\downarrow \downarrow$ & $\downarrow \downarrow$ & $\downarrow \downarrow$ & $\downarrow \downarrow \downarrow$ & $\downarrow \downarrow$ & $\downarrow \downarrow$ & $\downarrow \downarrow \downarrow$ & $\downarrow \downarrow$ & $\mathrm{N}$ & $\mathrm{N}$ \\
\hline IJspeert et al. [17], 2011 & 1 & 6 & $\mathrm{~N}-\downarrow$ & $\downarrow$ & $\downarrow$ & & $\downarrow$ & $\downarrow$ & $\downarrow$ & $\mathrm{N}$ & $\mathrm{N}$ & $\mathrm{N}$ \\
\hline Jak3 deficiency & & & $\downarrow$ & $\downarrow$ & $\downarrow$ & & $\mathrm{N}-\uparrow$ & $\downarrow$ & & & & $\downarrow \downarrow-\downarrow$ \\
\hline Gregoriou et al. [18], 2008 & 1 & 6 & $\downarrow \downarrow$ & $\downarrow \downarrow$ & $\downarrow$ & & & & $\downarrow \downarrow$ & $\mathrm{N}$ & & $\downarrow \downarrow$ \\
\hline HLA class I deficiency (TAP deficiency & & & $\mathrm{N}$ & $\mathrm{N}$ & $\mathrm{N}$ & & $\mathrm{N}$ & & $\mathrm{N}$ & $\downarrow$ & & \\
\hline Mertens et al. [20], 2000 & 1 & 34 & & & & & & & & $\downarrow$ & & $\uparrow$ \\
\hline Villa Forte et al. [21], 2008 & 1 & 20 & & & & & $\mathrm{~N}$ & & & $\downarrow$ & $\uparrow$ & $\mathrm{N}$ \\
\hline Griscelli syndrome & & & $\mathrm{N}$ & $\mathrm{N}$ & $\mathrm{N}$ & & $\mathrm{N}$ & $\mathrm{N}$ & & & & abnormal \\
\hline Eyer et al. [22], 1998 & 1 & 3 & & & & & & & & & & \\
\hline Common variable immunodeficiency & & & $\downarrow$ & $\mathrm{N}-\downarrow \downarrow \downarrow$ & $N-\downarrow \downarrow \downarrow$ & $\downarrow$ & $\mathrm{N}-\downarrow \downarrow$ & $\mathrm{N}-\downarrow \downarrow$ & $N-\downarrow \downarrow$ & & $\mathrm{N}$ & $\mathrm{N}$ \\
\hline $\begin{array}{l}\text { Ardeniz and Cunningham-Rundles } \\
{[23], 2009}\end{array}$ & 7 & 14 & $\downarrow \downarrow \downarrow$ & $\downarrow \downarrow$ & $\downarrow \downarrow$ & & $\mathrm{N}$ & & & & & \\
\hline & & 16 & $\downarrow \downarrow$ & $\downarrow \downarrow$ & $\downarrow$ & & $\downarrow$ & & & & & \\
\hline & & 22 & $\downarrow$ & $\downarrow \downarrow$ & $\downarrow \downarrow$ & & $\downarrow \downarrow$ & & & & & \\
\hline & & 27 & $\downarrow \downarrow$ & $\downarrow \downarrow$ & $\downarrow \downarrow$ & & $\downarrow$ & & & & & \\
\hline & & 37 & $\downarrow \downarrow$ & $\downarrow \downarrow$ & $\downarrow$ & & $\downarrow$ & & & & & \\
\hline & & 44 & $\downarrow$ & $\downarrow$ & $\mathrm{N}$ & & & & & & & \\
\hline
\end{tabular}

$\mathrm{N}=$ Normal; $\uparrow$ = increased; $\uparrow \uparrow=$ moderately increased; $\uparrow \uparrow \uparrow=$ markedly increased; $\downarrow=$ decreased; $\downarrow \downarrow=$ moderately decreased; $\downarrow \downarrow \downarrow=$ markedly decreased.

had this hyper-IgM phenotype. Indeed, switched memory B cells, determined in 2 of them, were absent [Driessen et al., in preparation]. Further, we noticed that by the time of diagnosis of the cutaneous granulomas in our A-T patients, they all had a markedly reduced number of CD19+ $B$ cells and CD3+CD4+CD45RA+ naïve T cells (table 1). This immunological profile is distinct from that observed in our patients at an earlier stage and also differs from that reported in the literature for A-T patients without skin granulomas [30]. Interestingly, the same immunological disturbances were mentioned in the A-T patient with cutaneous granulomas of Folgori et al. [13] (table 1) and in the patients with cutaneous granulomas associated with RAG deficiency [16] and Artemis deficiency [17] (table 2). CVID patients, par- ticularly those with B- and T-cell lymphopenia and reduced switched memory $\mathrm{B}$ cells, are also more prone to granulomatous disease [28, 31]. Resolution of cutaneous granulomas in RAG deficiency and Artemis deficiency have been noted after haematopoietic stem cell transplantation $[16,17]$.

In none of the A-T patients with skin granulomas was an infective cause demonstrated. Cultures and staining for micro-organisms in all 17 reported patients as well as in all our 4 patients were negative. In several patients, the granulomas developed after minor injuries. The propensity for granulomas to appear on the limbs (trauma-prone area) may be related to impaired wound healing and tissue repair in these immunodeficient patients. The marked decrease in $\mathrm{B}$ cells and naïve
T cells in our A-T patients coinciding with the appearance of the cutaneous granulomas (table 1) suggests that the immunopathology of these skin lesions may be secondary to impaired B-cell- or T-cell-mediated immune regulation.

Dermal wound healing is a complex sequential process that involves the integration of chemotaxis of inflammatory cells, migration of keratinocytes and remodelling of scar tissue. T cells, B cells and various key growth factors and enzymes work in synergy to orchestrate the healing process [32]. CD19 is a positive-response regulator of B cells, which plays a critical role in wound healing as is shown by the observation that CD19 deficiency in mice inhibits wound healing [33]. Macrophages exert different roles at diverse stages of the repair response, and they orchestrate the 
natural sequence of repair phases in skin, which are essential to restore solid tissue homeostasis and integrity after injury [34]. Macrophages are activated in response to various cytokines, including interferon- $\gamma$ (IFN- $\gamma$ ) [35] that is produced by NK cells [36] and by T cells. The crucial role of IFN$\gamma$ in the induction of granulomas is illustrated by the inability of patients with a defective IFN- $\gamma$ signalling pathway to form mature granulomas in response to mycobacterial infections [37]. The importance of NK cells is illustrated by the occurrence of granulomas in patients with TAP deficiency who lack, by the absence of HLA class I molecules, the ability to turn off NK cell activity and thus NK-cell-derived IFN- $\gamma$ production $[19,38]$. In A-T patients, the amount of intracellular IFN- $\gamma$ in NK cells is not different from controls [30], and NK cell numbers were normal in our A-T patients and also in patients with RAG deficiency and Artemis deficiency (table 1 and 2). However, in the patient with JAK3 deficiency and granulomas, NK cells were absent.

An appropriate on-off $\mathrm{T}$ cell response requires proliferation of naïve $\mathrm{T}$ cells with a normal, unrestricted TCR repertoire [39]. In A-T, the TCR repertoire is skewed as it was in the patient with skin granulomas reported by Folgori et al. [13]. Simi- larly, an abnormal TCR repertoire has been reported in the patients with $\mathrm{RAG}$ deficiency and in patients with CVID who display granulomas. Specific CD4+ Th1 lymphocytes recognize, via their $\alpha \beta$ TCR complex, peptide antigens presented by macrophages on major histocompatibility class II molecules [40]. Although most T cells bear the TCR $\alpha \beta$ complex, a small subpopulation of about $5 \%$ have a distinct TCR composed of $\gamma$ - and $\delta$-subunits. For non-peptide antigens, as encountered in Mycobacterium infections, IFN- $\gamma$ comes mainly from these $\gamma \delta$ T cells which recognize antigens that are not presented in the major histocompatibility class II context [41]. T cells bearing $\gamma \delta$-receptors are present in patients with A-T [42], NBS, RAG deficiency and Artemis deficiency. In the patient with JAK3 deficiency and skin granulomas, the presence of $\gamma \delta$ T cells was not investigated; however, $\gamma \delta \mathrm{T}$ cells were demonstrated in other patients with this defect [43]. In patients with TAP deficiency, $\gamma \delta \mathrm{T}$ cells are elevated, and autoreactive NK and $\gamma \delta$ T cells were demonstrated [38]. Both NK cells and $\gamma \delta$ T cells have been reported to be important in the development of cutaneous granulomas [37, 38, 40, 4446].

IL-10 is a cytokine, derived from Th2 cells, that inhibits Th1-derived IFN- $\gamma$ pro- duction $[47,48]$. Thus, whereas granuloma induction requires IFN- $\gamma$, the resolution of granulomas needs IL-10. This means that appropriate activation of both specific Th1 cells and Th2 cells is crucial for an appropriate induction and cessation of a granulomatous response.

We propose that in patients with immunodeficiencies like A-T, NBS, deficiencies of RAG, Artemis and CVID, macrophages cannot function appropriately due to the lack of naïve (CD4+CD45RA+) T cells with a functional unrestricted TCR repertoire on CD4+ Th1 and Th2 cells. Whereas NK cells and/or $\gamma \delta \mathrm{T}$ cells will continue to activate the macrophages in the skin, this activation cannot be downregulated due to the absence of a counterregulatory IL-10 production by a specific CD4+ cell population.

In conclusion, we report that a subset of A-T patients with deficiencies of IgG, IgA and normal or even increased levels of IgM (the so-called hyper-IgM phenotype) is more likely to develop cutaneous granulomas. We postulate that the aetiology of these granulomas is related to immune dysregulation as suggested by a marked reduction of peripheral CD19+ B cells, a low number of CD3+CD4+CD45RA+ naïve $\mathrm{T}$ cells in the presence of normal NK cells and $\gamma \delta$ T cells.

\section{References}

$>1$ Savitsky K, Bar-Shira A, Gilad S, Rotman G, Ziv Y, et al: A single ataxia telangiectasia gene with a product similar to PI-3 kinase. Science 1995;268:1749-1753.

$>2$ Waldmann TA, Broder S, Goldman CK, Frost K, Korsmeyer SJ, Medici MA: Disorders of B cells and helper T cells in the pathogenesis of the immunoglobulin deficiency of patients with ataxia telangiectasia. J Clin Invest 1983;71:282-295.

-3 International Union of Immunological Societies Expert Committee on Primary Immunodeficiencies, Notarangelo LD, Fischer A, Geha RS, Casanova JL, Chapel H, Conley ME, Cunningham-Rundles C, Etzioni A, Hammartröm L, Nonoyama S, Ochs HD, Puck J, Roifman C, Seger R, Wedgwood J: Primary immunodeficiencies: 2009 update. J Allergy Clin Immunol 2009; 124:1161-1178.

4 Fleck RM, Myers LK, Wasserman RL, Tigelaar RE, Freeman RG: Ataxia-telangiectasia associated with sarcoidosis. Pediatr Dermatol 1986;3:339-343. $\checkmark 5$ Paller AS, Massey RB, Curtis MA, Pelachyk JM, Dombrowski HC, Leickly FE, et al: $\mathrm{Cu}$ taneous granulomatous lesions in patients with ataxia-telangiectasia. J Pediatr 1991; 119:917-922.

6 Joshi RK, al Asiri RH, Haleem A, Abanmi A, Patel CK: Cutaneous granuloma with ataxia telangiectasia - a case report and review of literature. Clin Exp Dermatol 1993;18:458461.

7 Götz A, Eckert F, Landthaler M: Ataxia-telangiectasia (Louis-Bar syndrome) associated with ulcerating necrobiosis lipoidica. J Am Acad Dermatol 1994;31:124-126.

-8 Drolet BA, Drolet B, Zvulunov A, Jacobsen $\mathrm{R}$, Troy J, Esterly NB: Cutaneous granulomas as a presenting sign in ataxia-telangiectasia. Dermatology 1997;194:273-275.

$\checkmark 9$ Murakawa GJ, McCalmot T, Frieden IJ: Chronic plaques in a patient with ataxia telangiectasia. Cutaneous granulomatous lesions in a patient with AT. Arch Dermatol 1998;134:1145-1148.
10 Sentürk N, Hindioğlu U, Sahin S, Gököz A: Granulomatous skin lesions in a patient with ataxia telangiectasia. Br J Dermatol 1998; 139:543-544.

11 Corbisier A, Eschard C, Motte J, Munzer M, Barhoum K, Kalis B, Grosshans E: Lésions granulomateuses cutanées révélatrices d'une ataxie-télangiectasie. Ann Dermatol Vénéréol 1999;126:608-611.

12 Mitra A, Pollock B, Gooi J, Darling JC, Boon A, Newton-Bishop JA: Cutaneous granulomas associated with primary immunodeficiency disorders. Br J Dermatol 2005;153: 194-199.

13 Folgori L, Scarselli A, Angelino G, Ferrari F, Antoccia A, Chessa L, et al: Cutaneous granulomatosis and combined immunodeficiency revealing ataxia-telangiectasia: a case report. Ital J Pediatr 2010;36:29.

14 Yoo J, Wolgamot G, Torgerson TR, Sidbury $\mathrm{R}$ : Cutaneous noncaseating granulomas associated with Nijmegen breakage syndrome. Arch Dermatol 2008;144:418-419. 
15 Vogel C, Stratman E, Reck S, Lund J: Chronic noninfectious necrotizing granulomas in a child with Nijmegen breakage syndrome. Pediatr Dermatol 2010;27:285-289.

$\checkmark 16$ Schuetz C, Huck K, Gudowius S, Megahed M, Feyen O, Hubner B, et al: An immunodeficiency disease with RAG mutations and granulomas. N Engl J Med 2008;358:20302038.

17 Ijspeert $\mathrm{H}$, Lankester AC, van den Berg JM, Wiegant W, van Zelm MC, Weemaes CMR, Warris A, Pan-Hammerström, Pastink A, van Tol MJD, van Dongen JJM, van Gent DC, van der Burg M: Artemis splice defects cause atypical SCID and can be restored in vitro by an antisense oligonucleotide. Genes Immun 2011, E-pub ahead of print.

18 Gregoriou S, Trimis G, Charissi C, Kalogermitros D, Stefanaki K, Rigopulos D: Cutaneous granulomas with predominantly CD $8(+)$ lymphocytic infiltrate in a child with severe combined immunodeficiency. J Cutan Med Surg 2008;12:246-248.

19 Moins-Teisserenc HM, Gadola SD, Cella M, Dunbar PR, Exley A, Blake N, Baycal C, Lambert J, Bigliardi P, Willemsen M, Jones M, Buechner S, Colonna M, Gross WL, Cerundolo V: Association of a syndrome resembling Wegener's granulomatosis with low surface expression of HLA class I molecules. Lancet 354:1598-1603.

20 Mertens G, Desmet D, Gielis M: A case of chronic granulomatous skin disease associated with deficient HLA class I expression. Br J Dermatol 2000;143:659-660.

21 Villa-Forte A, de la Salle H, Fricker D, Hentges F, Zimmer J: HLA class I deficiency syndrome mimicking Wegener's granulomatosis. Arthritis Rheum 2008;58:2579-2582.

22 Eyer D, Petiau P, Finck S, Heid E, Grosshans E, Lutz P: Lésions granulomateuses cutaneés au cours d'une maladie de Griscelli. Ann Dermatol Vénéréol 1998;125:727-728.

23 Ardeniz O, Cunningham-Rundles C: Granulomatous disease in common variable immunodeficiency. Clin Immunol 2009;133: 198-207.

24 Gallerani I, Innocenti D, Coronella G, Berti S, Amato L, Moretti S, Fabbri P: Cutaneous sarcoid-like granulomas in a patient with $\mathrm{X}$ linked hyper-IgM syndrome. Pediatr Dermatol 2004;21:39-43.

25 Paradela S, Sacristán F, Almagro M, Prieto V, Kantrow S, Fonseca E: Necrotizing vasculitis with a polyarteritis nodosa-like pattern and selective immunoglobulin A deficiency: case report and review of the literature. J Cutan Pathol 2008;35:871-875.
26 Fleming M, Gewurz A, Pearson R: Caseating cutaneous granulomas in a patient with $\mathrm{X}$ linked infantile hypogammaglobulinemia. J Am Acad Dermatol 1991;24:629-633.

27 de Jager M, Blokx W, Warris A, Bergers M, Link M, Weemaes C, Seyger M. Immunohistochemical features of cutaneous granulomas in primary immunodeficiency disorders: a comparison with cutaneous sarcoidosis. J Cutan Pathol 2008;35:467-472.

28 Malphettes M, Gérard L, Carmagnat M, Mouillot G, Vince N, Boutboul D, et al: Lateonset combined immune deficiency: a subset of common variable immunodeficiency with severe T cell defect. Clin Infect Dis 2009;49: 1329-1338.

29 Giovannetti A, Mazzetta F, Caprini E, Aiuti A, Marziali M, Pierdominici M, Cossarizza A, Chessa L, Scala E, Quinti I, Russo G, Fiorilli M: Skewed T cell receptor repertoire, decreased thymic output and predominance of terminally differentiated $\mathrm{T}$ cells in ataxia telangiectasia. Blood 2002;100:4083-4089.

30 Schubert R, Reichenbach J, Zielen S: Deficiencies in $\mathrm{CD} 4+$ and CD8+ $\mathrm{T}$ cell subsets in ataxia telangiectasia. Clin Exp Immunol 2002;129:125-132.

31 Mullighan CG, Fanning GC, Chapel HM, Welsh KI: TNF and lymphotoxin-alpha polymorphisms associated with common variable immunodeficiency: role in the pathogenesis of granulomatous disease. J Immunol 1997;159:6236-6241.

-32 Takamiya M, Fujita S, Saigusa K, Aoki Y: Simultaneous detection of eight cytokines in human dermal wounds with a multiplex bead-based immunoassay for wound age estimation. Int J Legal Med 2008;122:143148.

33 Iwata Y, Yoshizaki A, Komura K, Shimizu K, Ogawa F, Hara T, et al: CD19, a response regulator of B lymphocytes, regulates wound healing through hyaluronan-induced TLR4 signaling. Am J Pathol 2009;175:649-660.

34 Lucas T, Waisman A, Ranjan R, Roes J, Krieg T, Müller W, et al: Differential roles of macrophages in diverse phases of skin repair. J Immunol 2010;184:3964-3977.

35 Fairweather D, Cihakova D: Alternatively activated macrophages in infection and autoimmunity. J Autoimmun 2009;33:222230.

36 Takashima T, Ohnishi K, Tsuyuguchi I, Kishimoto S: Differential regulation of formation of multinucleated giant cells from concanavalin A-stimulated human blood monocytes by IFN-gamma and IL-4. J Immunol 1993;150:3002-3010.
37 Lammas DA, De Heer E, Edgar JD, Novelli V, Ben-Smith A, Baretto R, et al: Heterogeneity in the granulomatous response to mycobacterial infection in patients with defined genetic mutations in the interleukin 12dependent interferon-gamma production pathway. Int J Exp Pathol 2002;83:1-20.

38 Gadola SD, Moins-Teisserenc HT, Trowsdale J, Gross WL, Cerundolo V: TAP deficiency syndrome. Clin Exp Immunol 2000;121: 173-178.

39 Fietta P, Delsante G: The effector T helper cell triade. Riv Biol 2009;102:61-74.

40 James DG: What makes granulomas tick? Thorax 1991;46:734-736.

41 Janis EM, Kaufmann SH, Schwartz RH, Pardoll DM: Activation of gamma delta T cells in the primary immune response to $\mathrm{Myco}$ bacterium tuberculosis. Science 1989;244: $713-716$.

42 Carbonari M, Cherchi M, Paganelli R, Giannini G, Galli E, Gaetano C, et al: Relative increase of $\mathrm{T}$ cells expressing the gam$\mathrm{ma} /$ delta rather than the alpha/beta receptor in ataxia-telangiectasia. N Engl J Med 1990; 322:73-76.

43 Frucht DM, Gadina M, Jagadeesh GJ, et al: Unexpected and variable phenotypes in a family with JAK3 deficiency. Genes Immun 2001;2:422-432.

44 Plattner BL, Doyle RT, Hostetter JM: Gamma-delta $\mathrm{T}$ cell subsets are differentially associated with granuloma development and organization in a bovine model of mycobacterial disease. Int J Exp Pathol 2009;90:587597.

45 Battistini L, Caccamo N, Borsellino G, Meraviglia S, Angelini DF, Dieli F, et al: Homing and memory patterns of human gammadelta $\mathrm{T}$ cells in physiopathological situations. Microbes Infect 2005;7:510-517.

46 Puan KJ, Jin C, Wang H, Sarikonda G, Raker AM, Lee HK, et al: Preferential recognition of a microbial metabolite by human Vgamma2Vdelta2 T cells. Int Immunol 2007;19: 657-673.

47 Fiorentino DF, Bond MW, Mosmann TR Two types of mouse $\mathrm{T}$ helper cell. IV. Th2 clones secrete a factor that inhibits cytokine production by Th1 clones. J Exp Med 1989; 170:2081-2095.

-48 Fiorentino DF, Zlotnik A, Vieira P, Mosmann TR, Howard M, Moore KW, et al: IL-10 inhibits cytokine production by activated macrophages. J Immunol 1991;147:38153822 . 